\title{
Enquête
}

Archives de la revue Enquête

1 | 1985

À propos des cultures populaires

\section{Exercice final}

\section{(2) OpenEdition}

1 Journals

Édition électronique

URL : http://journals.openedition.org/enquete/189

DOI : $10.4000 /$ enquete. 189

ISSN : 1953-809X

Éditeur :

Cercom, Éditions Parenthèses

Édition imprimée

Date de publication : 2 avril 1985

\section{Référence électronique}

«Exercice final », Enquête [En ligne], 1 | 1985, mis en ligne le 03 juin 2013, consulté le 25 avril 2019.

URL : http://journals.openedition.org/enquete/189 ; DOI : 10.4000/enquete.189

Ce document a été généré automatiquement le 25 avril 2019. 


\section{Exercice final}

Trouver l'énigme que la sphinge des cultures populaires pose au sociologue.

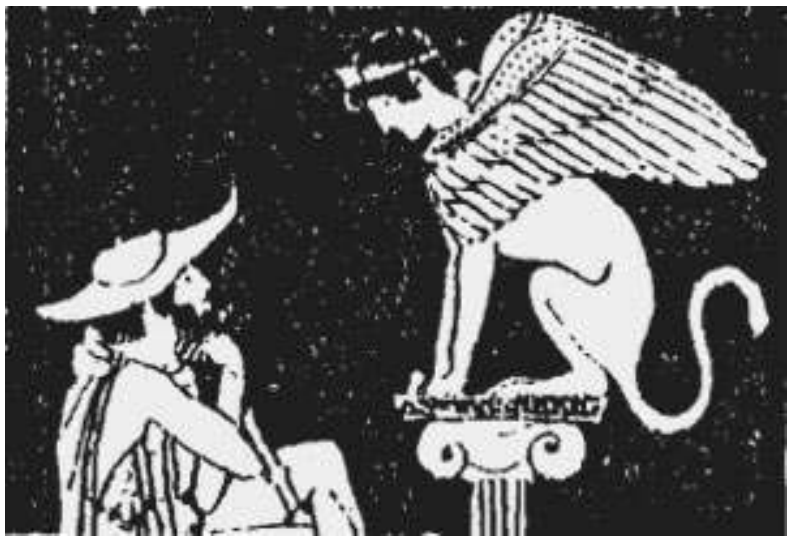

